\title{
Erratum to: Analysis of variability and antigenic peptide prediction of E2 BVDV glycoprotein in a mucosal-disease affected animal
}

\author{
S. Ciulli • E. Galletti • M. Battilani • V. Galligioni • \\ S. Prosperi
}

Published online: 15 October 2009

(C) Springer Science + Business Media B.V. 2009

\section{Erratum to: Vet Res Commun (2009) 33 (Suppl 1):S125-S127 DOI 10.1007/s11259-009-9267-7}

The original version of this article unfortunately contained a mistake. The surname of one of the authors was incorrect. "Galligione" should have been "Galligioni".

The online version of the original article can be found at http://dx.doi.org/10.1007/s11259-009-9267-7.

S. Ciulli $\cdot$ E. Galletti $\cdot$ M. Battilani $\cdot$ V. Galligioni $\cdot$ S. Prosperi

Dipartimento di Sanità Pubblica Veterinaria e Patologia Animale, Alma Mater Studiorum,

Università di Bologna, Bologna, Italy

S. Ciulli $(\bowtie)$

Dipartimento di Sanità Pubblica Veterinaria e Patologia Animale, Alma Mater Studiorum, Viale Vespucci, 2, 47042 Cesenatico (FC), Italy

e-mail: sara.ciulli@unibo.it 